\title{
Poetic Beauty of Sarojini Naidu's Poetries
}

\section{Dr. Mithilesh Kumar Manjhi}

Asst. Prof. (Guest), J.N. College, Madhubani, Bihar, India

\begin{abstract}
Sarojini Naidu, the nightingale of India, was a talented craftsman whose verse is unadulterated and loaded with extraordinary desire. She was acutely alive to all the delights and bounties of nature. She is captivated by the sights and sounds, hues and smells of common items. She has attempted to include all characteristic articles in her verse. She has composed sonnets on a wide range of trees, blossoms, fowls and seasons too. In her verse, there is finished congruity between man, nature and legend. Her sonnets uncover an unconstrained comprehension and significance of man's relationship with nature. Nature was a spring of unending ecstasy to her.' Nature has for quite some time been a wellspring of motivation to the artists to create their sonnets and has stayed as a compelling energizer to uncover their feelings recalled in serenity. The issues of contemporary Indian culture are unequivocally introduced through legends, images, and complex nature pictures. They have been enthused to set their renderings to the changes of the scene, the adjustments in season, to the tweeting of flying creatures, the murmuring of the honey bees, to the stirring sound of the leaves and any characteristic marvels around them. Nature and writing have consistently shared a cozy relationship as is proven in progress of artists and different scholars down the ages in practically all societies of the world.
\end{abstract}

Keywords - Nightingale of India, nature, Unconstrained comprehension, ecstasy, unequivocally.

The verse of Sarojini Naidu made a characteristic of noticeable quality in the field of Indian Poetry in English and is a significant piece of ladies' composition. Naidu is one of the renowned poetesses of Indo-Anglian verse. She had sharp tasteful reasonableness also, was an admirer of the shifted shades of Indian customs also, society life. Her verse is unadulterated and brimming with serious yearning blossoming with scent of assortment of topics like love of freedom, contempt of oppression and recovery of her own nation. The current paper illuminates various parts of Naidu as a writer and spotlights on the sonnets composed by Sarojini Naidu which portray lives of humble people of India and their custom. In pre-freedom Indian English verse, she is viewed as a vigorous, flexible and dynamic virtuoso who is unparalleled for her sweet and musical melodies. The three volumes of her sonnets The Golden Threshold (1905), The Bird of Time (1912) also, The Broken Wing (1917) involve a position of greatness in the history of Indo-Anglian verse. Her melodies are in incredible convention of Indian reverential writing - the writing which effectively and delightfully outlines and investigates the Vedantic and Upanishadic theory of affection, truth, harmony, God, everlasting status of the Supreme soul, strict confidence, selfrealization and so on. The topics and foundation of her verse were simply Indian and she sang in full-throated simplicity of the celebrations, occupations and life of her kin as a genuine girl of her country. Lyricism, her unconstrained flood of feelings saturated with Indian ethos and culture, the distinctiveness of symbolism, her effortlessness of articulation, imagery, mystery, local, enthusiasm, her energetic want for excellence, music and tune, or more all, her exciting and cadenced language. Calcutta: Orient Longmans, 1961. H.M. Prasad rightly holds the view: "Sarojini Naidu writes instant poetry when images and metaphors come rolling ready on the hot plates of imagination. Her poetry is intensely emotional, at times passionate to the point of eroticism and always has a springlike lyricism" 1.

Additionally, Indianness is a fascinating part of the verse of Sarojini Naidu. The sonnets in her first assortment of sonnets named The Golden Threshold in 1905 were acknowledged for their Indianness. The impulse of Edmund Gosse is tremendous from this viewpoint. Naidu believes him to be her abstract Godfather as he was the person who exhorted her to copy her sonnets, dispose of the fake English Vein totally and from this time forward utilize her sections to 
brighten the orient before a Western crowd: "I implored her to consider that from a young Indian of extreme sensibility who had mastered not merely the language but prosody of the West, what we wished to receive was ......... some revelation of the heart of India, some sincere penetrating analysis of narrative passion, of intimations as stirred the soul of the East long before the west had started to dream it had a soul". This prophetic counsel was the greatest impact on Sarojini Naidu. Subsequently, Indianness which suggests Indian not just in the selection of subjects and assumptions yet additionally in setting, symbolism and lingual authority turns into the significant part of the verse of Naidu.

Sarojani Naidu picked up acclaim as a writer. Her sonnets, full ofsoaring way of talking and conclusion found various admirers. The second assortment of Sarojini Naidu's sonnets The Bird of Time, was distributed in 1912 in London by William Heinemann, it had the presentation by Edmond Gosse. It includes 46 verses. Gosse adulated it exceptionally and found the sonnets substantially more develop than those which Sarojini Naidu had appeared to him quite a while prior. The assortment got incredible audits. The London Times said: "Fine expression of her nature rich in emotion, to find an Indian atmosphere making fragrant English poems is a rare pleasure." 2

At that point the third assortment of Sarojini Naidu's sonnets, The Broken Wing was distributed in 1917. It has 61 verses. Tagore praised the poems saying, "Your poems in 'The Broken Wing' seen to be made of tears and fire like the clouds of a July evening glowing with the muffled passion of sunset." 3 There are many Sarojini Naidu's sonnets that can't exist outside the Indian scene. They inhale the demeanor of India and can endure just in it. One such sonnet, relatively less known, is 'In Praise of Henna' in which the Indian ladies are gathering the leaves of the henna tree with which they can paint their hands and feet red:

"A Kokila called from a henna-spray:

Lira! Liree! Lira!Liree!

Hasten maidens, hasten away

To gather the leaves of the henna-tree.

The tilka's red for the brow of a bride,

And betel-nut's red for lips that are sweet;

But for lily-like fingers and feet,

The red, the red of the henna-tree" 4 .

The sonnet epitomizes the association of nature with man in a custom, which is as yet pervasive and communicates with an uncommon delicacy and the interest of Indian excellence. Naidu has extended basic Indian existence with practically striking exotic nature. "Palanquin Bearer," is the much ISSN: 2456-7620 anthologized first sonnet in The Golden Threshold. This sonnet invokes the musical development of the men conveying palanquins:

"Lightly, lightly, we bear her along

She sways like a flower in the wind of our song;

She skims like a bird on the foam of a stream,

She floats like a laugh from the lips of dream..." 5

The trouble of a leaving feathered creature and the delight of those accompanying her to her new home the phases of the inflexible walk of human life, communicated through a shaking cadence and an inestimable symbolism.

"She sways like a bird on the foam of a stream.........

She hangs like a star in the dew of our song;

She springs like a beam on the brow of the tide....." 6

At that point, another sonnet "Bangle Sellers" is likewise a beguiling verse portraying the employment of bangle dealers. Bangles are the image of glad ladies and wedded ladies which is communicated in the initial lines of the sonnet by Naidu along these lines:

"Bangle sellers are we who bear

Our shining loads to the temple fair.........

Who will by these delicate, bright Rainbow-tinted circles of light?

Lustrous tokens of radiant lives.

For happy daughters and happy wives"

Every one of the four refrains portrays bangles of various tones that will coordinate the ladies wearing them; 'rainbowcolored circles of light', for glad girls and spouses; 'silver and blue as the mountain fog' for a lady; 'sunlit corn' and 'the fire of her marriage fire' for the lady; 'purple and gold-spotted dim' for the lady who has 'ventured through life halfway.' In her verse one discovers Indian weavers weaving in changing hues robe of another conceived youngster, the marriage cover of a sovereign and a dead man's memorial service cover; the snake charmer who charms with his enchantment woodwind call 'the silver-breasted moon light emission', the corn processors singing a wretched tune; Indian artists moving 'eyes violated with happiness, endlessly gasping', the wanderer young lady in 'worn out robes' and so on. In addition, different Indian celebrations like Raksha Bandhan, Diwali, Vasantpanchami and Nagapanchami discover a spot in her verse.

Further, "Village Song" is a legendary, magical and emblematic sonnet by Sarojini Naidu. It bargains the common dread of a town lady that has gone to get a container of water from the waterway, Yamuna, The street is long and desolate and the night will eat up the day very soon. 
Subsequent to having topped off her pitchers, she is in a rush to restore her home. Yet, she is confined by the melody of the boatman. She is such a great amount of intrigued by the melody that she neglects to return and remains to tune in to the tune thus she gets late. One the other hand, the shadows of night are falling:

"Full are my pitchers and far to carry

Lone is the way and long

Why, $O$ why was I tempted to tarry

Lured by the boatman's song?

Swiftly the shadows of night are falling

Hear, O hear, is the white crane calling

Is it the wild old cry?" 8

In this sonnet, the poetess gives the trace of getting the salvation of the spirit from the subjugation of body. She says that the man who drives an existence of gravity and renunciation follows the strides of God and accordingly, prevails with regards to appending the incomparable euphoria. The town young lady in this sonnet is encircled by the dread of dimness, tempest, downpour and snake. In any case, over the long haul, she finds an answer for commit her full confidence in the presence of God with the goal that he may aid her stride and guide her.

Naidu depicts Indian mysticism in "In Salutation to Eternal Peace", "The Soul's Prayer" and "To a Buddha Seated on a Lotus" expresses the poets experience of Buddha himself when she asks about how to attain 'diviner summits' or conquer or control "The Heavenward hunger of our soul.'

After that there are some poems which reveals the patriotic note such as "The Lotus", "Gokhale", "lokmanya Tilak", "Imperial Delhi", "To India", and "The Gift of India". In "The Lotus", the heavenly blossom turns into an allegory for the otherworldly character of Mahatma Gandhi. She had consistently been attracted to the nationalistic reason. It is through Mahatma Gandhi and Gopal Krishan Gokhale that she was started in to Indian National Congress. As a nationalist, she is a big fan of secularism:

"One heart are we to lone thee, o our mother,

One undivided, unadvisable soul,

Bound by one hope, one purpose, one devotion

Towards a great, divinely destined goal."

Naidu's satisfaction in Nature is uncovered in "The tunes of spring Time". The brilliant Indian scenes with its Gulmohars and Sirsar, Champak and lotus buds and Koels summon Indian blossoms and fowls and give her verse a remarkable Indian flavor. Her disposition to Nature is that of the English sentimentalist yet her verse is saturated with Indian shading and smell and sound:

ISSN: $2456-7620$

https://dx.doi.org/10.22161/ijels.55.29
"The earth is a fire like a humming bird's wings

And the sky like a king fisher's feather."

Consequently, we find in her verse the maintaining of the most noteworthy goals and estimations of religion and morals which incorporate fundamental solidarity all things considered, humanism or confidence in God. Also, the basic investigation of some chose sonnets of Sarojini Naidu gives her Indian bowed of brain, her jumping into the rich custom of enchantment and her rhythmical ability. She was the songbird of India who sang the interminable tune of life and passing, love and enthusiasm, empathy and excellence. K.R.S. Iyengar appropriately watches:

"She was, above all, sensitive to beauty, the beauty of living things, the beauty of holiness, the beauty of the Buddha's compassion, the beauty of Brindavan's Lord. She didn't specially seek out the bizarre, the exotic, the exceptional, but her poems lack neither variety nor the flavour of actuality........ she didn't cudgel herself towards explosive modernity. But she had genuine poetic talent and she was a wholesome and authentic singer",

Thus, we can say that the poetry of Sarojini Naidu made a mark of prominence in the arena of Indian Poetry in English and is an important part of women's writing. We find in her verse the maintaining of the most elevated standards also, estimations of religion and morals which incorporate basic solidarity all things considered, humanism or confidence in God. In addition, the basic investigation of some chose sonnets of Sarojini Naidu shows her Indian bowed of brain, her jumping into the rich convention of mystery and her rhythmical adroitness. She was the songbird of India who sang the endless melody of life and demise. Her verse is honestly the verse of nature. The affection for her of nature is demonstrated even in sonnets which aren't about the common world, however have another plan. Nature in the external condition of male, just as Sarojini looks at it with an uncorrupt, open peered toward wonder. The response of her to nature is honest and straightforward that method of a child that analyzes nature with interest and is hit with stunningness by the greatness of her and the riddle of her. It's the plain and furthermore the basic that captivates Sarojini; she closes the eyes of her on the ugly and furthermore the frightful in nature. We don't enter the verse of her any steady world view that depicts the association of God, Nature and Man. She's neither pantheistic like Wordsworth nor enormous like Tagore. The specialized capacity of her, the influence of her to choose words that are correct, her rich love and expression for phrases, the authority of her of tune, her enthusiastic 
warmth and force of excitement, her compliment of words and in particular her rich creative mind plainly fix us decide she'd genuine beautiful ability. The current examination paper is a good try to draw out the unmistakable qualities of Sarojini Naidu'spoetry in the feeling of her dazzling, craftsmanship and effortlessness of language, technique and style.

\section{REFERENCES}

[1] Prasad HM. Indian Poetry in English, Sterling Publication Private Limited, New Delhi, 1992, 22.

[2] Durvedi AN. Sarojini Naidu and Her Poetry. Allahabad: Kitab Mahal, 1981, 141.

[3] Hasi Banerjee. Sarojini Naidu: A Traditional Feminist, K.P. Bagchi\& Co., Calcutta, 1998, 97.

[4] Sarojini Naidu. The Sceptred Flute. Allahabad: Kitabistan, 1958, 13.

[5] Ibid, p 3.

[6] Ibid

[7] Ibid, p. 14.

[8] Sarojini Naidu. Village Song in the anthology Indian Poets in English ed. by H.M. Prasad.

[9] Iyengar KRS. Indian Writing in English, Sterling pub. Pvt. Ltd., New Delhi, 1994, 225. 